\author{
KaRolina KozioŁ \\ Uniwersytet Rzeszowski, Polska \\ University of Rzeszow, Poland
RAFAŁ PITERA
Uniwersytet Rzeszowski, Polska
University of Rzeszow, Poland

\title{
Kredyt bankowy jako podstawa zewnętrznego finansowania małych i średnich przedsiębiorstw sektora usług
}

\section{Bank Loan as the Basis for External Financing of Small and Medium-Sized Enterprises in Services Sector}

\begin{abstract}
Streszczenie: Artykuł podejmuje problematykę finansowania przedsięwzięć z sektora usług. Od kilkudziesięciu lat kredyty bankowe stanowią jedno z najważniejszych zewnętrznych źródeł finansowania przedsiębiorstw. Obok kapitału własnego, będącego podstawowym i jednocześnie głównym finansowaniem, to właśnie środki pochodzące z udzielanych przez banki kredytów pomagają zrealizować przedsięwzięcia przedsiębiorstw na terytorium Polski. Wart podkreślenia jest fakt oceny sytuacji finansowej podmiotów ubiegających się o środki pieniężne od banków. W opracowaniu zostały przedstawione najważniejsze dane ukazujące, w jak dużym stopniu przedsiębiorstwa usługowe sięgają po zewnętrzne źródła finansowania oraz jakie miejsce w tej strukturze zajmują kredyty bankowe. Celem artykułu jest próba oceny istotności i znaczenia środków pochodzących z kredytów i pożyczek bankowych na rozwój w sektorze usług. Z uzyskanych danych empirycznych na temat finansowania działalności przedsiębiorstw w Polsce oraz z badania przeprowadzonego na grupie przedsiębiorstw sektora usług jednoznacznie wynika, iż kredyty bankowe obok kapitałów własnych stanowią główne i jednocześnie najpopularniejsze źródło finansowania realizowanych inwestycji. Mimo coraz większej oferty alternatywnych form finansowania, w dalszym ciągu to środki pochodzące od banków stanowią najczęstszą formę wspomagania przedsiębiorstw.
\end{abstract}

\footnotetext{
Abstract: The article deals with the issue of financing projects from the services sector. Bank credits have been one of the most important external financing sources for enterprises for several decades. In addition to equity, which is the basic and at the same time the main financing, it is the funds from the loans granted by banks that help to carry out enterprises' undertakings on the territory of Poland. It is worth emphasizing the fact of assessing the financial situation of entities applying for cash from banks. The study presents the most important data showing how much service enterprises reach for external sources of financing and what place bank loans occupy in this structure. The aim of the article is to attempt to define the significance of funds from bank loans for the development in the services sector. The analysis of empirical data, as well as a survey on the financing of enterprises in Poland conducted on a group of 600 business entities in the services sector clearly state that bank loans, apart from equity, constitute the main and the most popular source of financing of implemented investments. Despite the growing offer of alternative forms of financing, funds from banks are still the most common form of business support.
} 
Słowa kluczowe: finansowanie działalności przedsiębiorstw; kapitał obcy; kredyt bankowy; źródła finansowania

Keywords: bank loan; financing of business activities; financing sources; foreign capital

Otrzymano: 17 grudnia 2017

Received: 17 December 2017

Zaakceptowano: 15 maja 2018

Accepted: 15 May 2018

\section{Sugerowana cytacja / Suggested citation:}

Kozioł, K., Pitera, R. (2018). Kredyt bankowy jako podstawa zewnętrznego finansowania małych i średnich przedsiębiorstw sektora usług. Prace Komisji Geografii Przemysłu Polskiego Towarzystwa Geograficznego, 32(2), 152-163 https://doi.org/10.24917/20801653.322.10

\section{WSTĘP}

Działalność gospodarcza prowadzona przez przedsiębiorcę może być finansowana kapitałem pochodzącym z różnorodnych źródeł. Kapitał jako podstawowy czynnik czy nakład, tuż obok pracy i ziemi, jest podstawą warunkującą rozwój, a przede wszystkim przetrwanie każdej firmy. Wyznacza on granice swobody ekonomicznej wyborów dokonywanych przez podmioty gospodarujące, z kolei jego poziom w silnym stopniu kształtuje ich możliwości inwestycyjne (Chęciński, 2015: 397).

Rozpatrując pochodzenie inwestowanego kapitału, możemy go podzielić na własny i obcy. Kapitał własny - pozyskiwany ze źródeł wewnętrznych (np. z zatrzymanego w całości zysku wypracowanego w przedsiębiorstwie) oraz ze źródeł zewnętrznych (np. wpływów z emisji akcji, zwiększenia udziałów). Kapitał obcy pozyskiwany jest tylko i wyłącznie z zewnętrznych źródeł finansowania, którymi są kredyty i pożyczki bankowe, a także wpływy z emisji papierów dłużnych oraz leasingu finansowego (NBP, 2015: 4).

Ogniwami gospodarki każdego kraju są jej trzy zasadnicze sektory: przemysł, rolnictwo i usługi. Dorównanie przedsiębiorstwom uczestniczącym w rynku jest nie lada wyzwaniem dla jednostek rozpoczynających działalność. Wprowadzanie coraz to nowych produktów, usług czy innowacyjnych technologii z jednej strony daje przewagę konkurencyjną większym podmiotom gospodarczym, z drugiej zaś - tego typu działania wymagają odpowiedniej wiedzy, doświadczenia, a co najważniejsze - nakładów finansowych, które często przewyższają możliwości, jakimi dysponują przedsiębiorstwa (Brzozowski, 2013). Firmy spełniające wymogi, tj. mające zdolność kredytową, często muszą skorzystać z zewnętrznych źródeł finansowania, jakimi są kredyty, aby być konkurencyjnym podmiotem mogącym sprostać wyzwaniom stawianym zarówno przez rynek, jak i przez jego uczestników.

W artykule sformułowano następującą hipotezę badawczą: kredyt bankowy stanowi podstawowy instrument zewnętrznego finansowania przedsiębiorstw sektora usług. Oprócz analizy badań ankietowych dokonano przeglądu literatury przedmiotu. Scharakteryzowano najważniejsze źródła finansowania, jakie są obecnie dostępne dla przedsiębiorstw w Polsce, a także zaprezentowano najważniejsze wyniki dotychczasowych badań i wyniki badań własnych. 


\section{KREDYT JAKO PODSTAWA FINANSOWANIA ZEWNĘTRZNEGO}

Kredyty są najbardziej rozpowszechnioną formą finansowania dłużnego wszystkich podmiotów gospodarczych. Pełnią one podstawową funkcję w pobudzaniu aktywności gospodarczej wszystkich podmiotów uczestniczących w rynku.

Dla podmiotów gospodarczych, decydujących się na zaciągnięcie zobowiązania finansowego pod inwestycje bądź na potrzeby rozpoczęcia lub rozszerzenia działalności gospodarczej, kluczową kwestią jest znajomość rodzajów kredytów i gamy produktów oferowanych przez banki. Prawo bankowe, a dokładnie art. 5 ustawy, wśród wielu czynności właściwych bankom wyróżnia m.in.: udzielanie kredytów, udzielanie i potwierdzanie gwarancji bankowych oraz otwieranie i potwierdzanie akredytyw, udzielanie pożyczek pieniężnych, operacje czekowe i wekslowe oraz operacje, których przedmiotem są warranty, udzielanie i potwierdzanie poręczeń.

Wymienione powyżej czynności mogą być wykonywane wyłącznie przez banki, odziały banków zagranicznych, odziały instytucji kredytowych lub inne jednostki organizacyjne uprawnione do tego na podstawie odrębnych przepisów ustawy. Zgodnie z przepisami jednostkami organizacyjnymi uprawnionymi do udzielania kredytów są także spółdzielcze kasy oszczędnościowo-kredytowe (Próchnicka-Grabias, Szelągowska, 2006: 14).

Kredyt bankowy jest zawartą $\mathrm{w}$ formie pisemnej umową pomiędzy bankiem a kredytobiorcą (art. 69 ust. 1 prawa bankowego). W krajowym systemie bankowym nie istnieje jeden kompleksowy, jednolity podział czy nazewnictwo kredytów udzielanych przez banki. Podmioty będące stronami umowy mogą same wpływać na kształt danej umowy i formy kredytu. Ze względu jednak na istotne elementy, które powinny zawierać umowy kredytowe, można wyodrębnić kilka ich typów i dokonać klasyfikacji kredytów według określonych kryteriów (NBP, 2015: 23).

Tab. 1. Podział kredytów z uwzględnieniem wybranych kryteriów

\begin{tabular}{|c|c|}
\hline \multicolumn{2}{|r|}{ Podział kredytów ze względu na kryteria } \\
\hline $\begin{array}{l}\text { Ze względu na przedmiot } \\
\text { (przeznaczenie) }\end{array}$ & $\begin{array}{l}\text { - obrotowe } \\
\text { - inwestycyjne }\end{array}$ \\
\hline $\begin{array}{l}\text { Ze względu na okres } \\
\text { kredytowania }\end{array}$ & $\begin{array}{l}\text { - krótkoterminowe } \\
\text { - średnioterminowe } \\
\text { - długoterminowe }\end{array}$ \\
\hline Ze względu na formę kredytu & $\begin{array}{l}\text { - w rachunku bieżącym } \\
\text { - w rachunku kredytowym } \\
\text { - dyskontowe } \\
\text { - akceptacyjne - jednorazowe } \\
\text { - związane ze skupem faktur } \\
\text { - w formie linii kredytowej nieodnawialnej i odnawialnej } \\
\text { - pomostowe }\end{array}$ \\
\hline $\begin{array}{l}\text { Ze względu na stawkę } \\
\text { procentową }\end{array}$ & $\begin{array}{l}\text { - o stałym oprocentowaniu } \\
\text { - o zmiennym oprocentowaniu } \\
\text { - o stało-zmiennej stopie procentowej }\end{array}$ \\
\hline Ze względu na preferencyjność & $\begin{array}{l}\text { - komercyjne } \\
\text { - preferencyjne }\end{array}$ \\
\hline $\begin{array}{l}\text { Ze względu na sposób spłaty } \\
\text { kredytu (kapitału i odsetek) }\end{array}$ & $\begin{array}{l}\text { - w stałych bądź zmiennych ratach kapitałowych } \\
\text { - annuitetowe } \\
\text { - kredyty, w których odsetki są płacone z góry bądź z dołu }\end{array}$ \\
\hline
\end{tabular}

Źródło: opracowanie własne na podstawie NBP (2015: 23-26) 
Prawidłowo zaciągnięty kredyt jest nie tylko instrumentem finansowania bieżącej działalności operacyjnej firmy, lecz także źródłem finansowania inwestycji, które staje się niezbędnym elementem rozwoju każdego przedsiębiorstwa (Korzeb, 2016: 140).

Udzielenie kredytu bankowego sprowadza się do oddania przez bank środków pieniężnych do dyspozycji kredytobiorcy. Kredytobiorca, korzystając z przeznaczonych środków, zobowiązuje się do spełnienia warunków opisanych w umowie kredytowej, czyli zwrotu zaciągniętej pożyczki wraz z odsetkami i prowizją w określonym terminie. Banki, jako oferenci produktów bankowych, stanowiących główne źródło ich dochodów, starają się dostosowywać swoją ofertę do rosnących potrzeb klientów, w tym kredytobiorców. Zobowiązania finansowe udzielane firmom i osobom fizycznym $w$ formie kredytu są jedną z podstawowych form działalności wielu instytucji bankowych.

Pojęcie zdolności kredytowej oznacza zdolność do spłaty zaciągniętego kredytu wraz z odsetkami w terminach określonych w umowie. W odniesieniu do podmiotów gospodarczych zdolność kredytową posiadają te firmy, których stan majątkowy oraz poziom efektywności finansowej prowadzonej działalności gospodarczej stwarzają pełne zabezpieczenie wykonania zobowiązań nie tylko wobec banku, ale i wobec wszystkich wierzycieli (art. 70 ust. 1 prawa bankowego).

Odnosząc się do ogólnego pojęcia zdolności kredytowej, warto nadmienić, iż w tym zakresie banki, udzielając kredytów podmiotom gospodarczym, mają dużą swobodę w ustaleniu głównych czynników warunkujących możliwą do zaciągnięcia kwotę kredytu. Należy zaznaczyć, iż czynniki te zależą zarówno od rodzaju banku, który tego kredytu udziela, rodzaju samego kredytu, jak i podmiotu, który o ten kredyt się ubiega. Charakteryzując zdolność kredytową, należy przytoczyć dwa rodzaje jej oceny. Mianowicie niemal w każdym przypadku bank dokonuje analizy czynników o charakterze ilościowym (mierzalnym), a także jakościowym (niemierzalnym, których wynik zależy od indywidualnego podejścia banku oraz przyjętych kryteriów oceny). Następnie bank ocenia te czynniki całościowo i na tej podstawie określa zdolność kredytową.

Odnosząc się do powyższych elementów, należy podkreślić, że - niezależnie od rodzaju banku - każdy bank musi stosować się do obowiązujących przepisów wynikających z prawa bankowego oraz różnego rodzaju rozporządzeń czy rekomendacji. Warto wspomnieć tylko o rekomendacjach Komisji Nadzoru Finansowego (KNF), która jako podmiot pełniący funkcję nadzorcy reaguje na występujące na rynku finansowym sytuacje i może wydać odpowiednie przepisy, ograniczające bądź zakazujące udzielania pewnych rodzajów kredytów, czy szerzej - produktów bankowych (nie tylko kredytowych).

Mimo norm i przepisów, każdy bank oddzielnie i w sposób dla siebie właściwy warunkuje ocenę zdolności kredytowej. W zależności od banku można spotkać się z podejściem bardziej restrykcyjnym bądź bardziej liberalnym - w granicach dopuszczonych przez prawo. 0 przyjętym podejściu i stosowanej polityce bankowej decydują zarządzający (Kitowski, 2014). Taka sytuacja może wynikać z wielu czynników, mianowicie - czy bank potrzebuje zdobyć nowych klientów kredytowych, czy ma wystarczające środki na udzielenie dużej liczby kredytów, na jaki segment klientów nastawia swoją działalność, a także czy jest bankiem dla klientów z segmentu prestige.

Analizując różnego rodzaju dane statystyczne, można stwierdzić, że najpopularniejszym źródłem zewnętrznego finansowania nadal są kredyty i pożyczki. Zatem charakterystyka tej właśnie formy finansowania staje się zasadna ze względu na wciąż dużą popularność wśród przedsiębiorców w Polsce. Wart podkreślenia jest fakt, iż 
mimo coraz większej liczby tzw. alternatywnych źródeł finansowania, w dalszym ciągu nie stanowią one istotnego procentu w strukturze środków wspierających finansowanie przedsięwzięć.

\section{KREDYT A SEKTOR USŁUG}

W teoriach ekonomicznych na przestrzeni kilkudziesięciu lat podkreślano znaczenie sektora usług w odniesieniu do siły roboczej oraz jej wysokiego udziału w zatrudnieniu - co wyjaśnia m.in. teoria A. Fishera, C. Clarka czy J. Fourastiégo. Jednocześnie, jak pisze J. Fourastié, to sektor usług cechuje najwolniejsza substytucja pracy przez kapitał, czyniąc ten sektor stabilnym w porównaniu do pozostałych. Także właśnie w usługach docenia się i wykorzystuje w największym stopniu wykwalifikowaną siłę roboczą (Cyrek, 2011: 452). W późniejszych teoriach można znaleźć bardziej krytyczne stanowiska względem sektora usług - określa się go jako ten sektor, który jest najmniej produktywny i nie przyczynia się do realnego wytwarzania produktów. Jednak w ostatnich kilkunastu latach badacze uznają sektor usług za ten, który nakierowany jest na społeczeństwo oparte na wiedzy i daje możliwości spełnienia i rozwoju zawodowego. Niemniej biorąc pod uwagę ostatnie kilkadziesiąt lat funkcjonowania gospodarek na świecie - to właśnie przemysł i usługi pełnią znaczącą funkcję w kształtowaniu nowych procesów, a mianowicie przejścia do gospodarki opartej na wiedzy. W zależności od struktury gospodarki poszczególnych państw, to przemysł lub usługi stanowią siłę napędową tych zmian (Zioło, 2013: 11-12).

W Polsce, podobnie jak i w wielu innych krajach, sektor usług stanowi kluczowy segment na rynku pracy. To właśnie w tej branży pracuje najwięcej osób. Takie zmiany w strukturze zatrudnienia są przede wszystkim wynikiem dwóch tendencji: przepływu osób z sektora przemysłowego do usługowego, a także równoczesnej migracji osób z rolnictwa do usług i do przemysłu (Skórska, 2016: 13-15). Według danych statystycznych z końca 2016 roku w większości państw europejskich dominującym sektorem, w którym ludność aktywna zawodowo znalazła miejsce pracy, jest branża usługowa. W zależności od państwa udział sektora usług wahał się w przedziale od niemal 40\% (Chiny, Rumunia) do ponad 75\% (Wielka Brytania, Luksemburg, Malta) (Mały rocznik statystyczny Polski, 2017: 120).

Jak podaje raport Ministerstwa Gospodarki: „Sektor usług ma w Polsce największy wkład w tworzenie wartości dodanej brutto i PKB $(63,8 \%)$. Widać, iż Polska powoli zbliża się do osiągnięcia struktury obserwowanej w krajach OECD, gdzie średni udział usług wynosi 70\%. W krajach OECD usługi rynkowe partycypują w ok. 50\% wartości dodanej w gospodarce, a usługi nierynkowe w ok. 20\% (w Polsce w 2014 roku odpowiednio 49,5\% i 14,3\%)" (Ministerstwo Gospodarki, 2015: 203).

Zgodnie z danymi z niniejszego raportu, mówiąc o strukturze podmiotowej sektora usług, w którym na koniec 2014 roku działało ok. 76,8\% firm zarejestrowanych w rejestrze REGON, można zauważyć wzrost o ok. 0,5\% w stosunku do poprzedniego roku. Spośród tych firm blisko 96,2\% to przedsiębiorstwa prywatne, w głównej mierze z sekcji: handel, naprawa pojazdów samochodowych (ponad $1 \mathrm{mln}$ firm), działalność profesjonalna naukowa i techniczna (385,1 tys. przedsiębiorstw) oraz transport i gospodarka magazynowa (252,5 tys. przedsiębiorstw) (Ministerstwo Gospodarki, 2015: 204).

Obserwowany od wielu lat rozwój sektora usług w Polsce znajduje odzwierciedlenie w danych charakteryzujących działalność gospodarczą podmiotów usługowych. 
W ciągu ostatnich kilkudziesięciu lat zdecydowanie wzrosło znaczenie tego sektora dla całej polskiej gospodarki. Podobnie jak w latach poprzednich, tak i w 2013 roku głównym źródłem finansowania działalności gospodarczej przedsiębiorstw z sektora usług były środki własne, które stanowiły 79,7\% wszystkich nakładów w sektorze usług. Natomiast wśród źródeł obcych najczęściej sięgano po kredyty bankowe - blisko 90\% w strukturze zewnętrznych źródeł finansowania (Ministerstwo Gospodarki, 2015: 212).

Zgodnie z danymi publikowanymi przez Związek Banków Polskich kredyt bankowy nadal pozostaje najważniejszym źródłem finansowania zewnętrznego dla polskich przedsiębiorstw - nie tylko z sektora usług, ale także z pozostałych działów gospodarki. Wartość kredytów bankowych udzielonych przedsiębiorcom z sektora usług przekroczyła próg 200 mld zł (201 mld zł na koniec kwietnia 2017 roku). Jednocześnie z przeprowadzonej analizy ZBP wynika, że kredyt bankowy stanowi w dalszym ciągu najłatwiejszą do pozyskania formę finansowania z zewnątrz (ZBP, 2017a). Podobna sytuacja występuje w segmencie małych i średnich przedsiębiorstw, w którym poza środkami własnymi to kredyty stanowią najważniejszą pozycję spośród dostępnych źródeł finansowania działalności gospodarczej.

Kredyt udzielany przez banki wymieniany jest jako najbardziej powszechne zewnętrzne źródło finansowania działalności przedsiębiorstw przez 48\% średnich firm (roczne obroty w przedziale 3,6-30 $\mathrm{mln} \mathrm{zł}$ ) oraz $37 \%$ mikro- i małych przedsiębiorstw (obroty do 3,6 mln zł). Zdecydowana większość przedsiębiorstw z obu segmentów - 89\% - w finansowaniu swojej działalności w dalszym ciągu preferuje wykorzystanie środków własnych - jak wynika z badania „Mikro-, małe i średnie przedsiębiorstwa o usługach finansowych”, zrealizowanego w drugim kwartale przez CBM Indicator we współpracy z Warszawskim Instytutem Bankowości i Związkiem Banków Polskich. Badanie zostało przeprowadzone wśród przeszło 1210 polskich przedsiębiorców metodą indywidualnych zestandaryzowanych wywiadów kwestionariuszowych (ZBP, 2017b).

Z badań na temat zewnętrznych źródeł finansowania przeprowadzonych przez Komisję Europejską we współpracy z Europejskim Bankiem Centralnym wynika, iż w sektorze usług to kredyty bankowe cieszą się wciąż największą popularnością. Mimo wielu różnych i coraz to nowych możliwości pozyskiwania kapitału, w dalszym ciągu środki pochodzące z banków stanowią najczęstszą pomoc dla przedsiębiorstw usługowych.

Może to oznaczać, iż alternatywne źródła finansowania, takie jak: finansowanie kapitałem zagranicznym venture capital, crowdfunding, szeroko rozumiana pomoc ze środków unijnych lub finansowanie dłużne, są trudno dostępne, możliwość skorzystania z takiej formy wsparcia ma wiele niejasności albo przekaz informacji na temat takich źródeł w społeczeństwie jest stosunkowo słaby. Dodatkowym utrudnieniem w przypadku omawianych źródeł jest procedura pozyskiwania środków pieniężnych. Równie ważnym problemem wydaje się brak jednolitych przepisów bądź częste modyfikacje już istniejących. Środki pochodzące ze źródeł alternatywnych wypadają znacznie słabiej w statystykach niż kredyty bankowe, które na tej płaszczyźnie jawią się jako bardziej uporządkowane i z podobną procedurą. Strukturę zewnętrznych źródeł fiansowania działalności gospodarczej sektora usług w Polsce na tle krajów UE przedstawia poniższa tabela. 
Tab. 2. Zewnętrzne źródła finansowania działalności gospodarczej sektora usług w Polsce na tle krajów UE

\begin{tabular}{|l|r|r|}
\hline \multicolumn{1}{|c|}{ Korzystanie z kredytów i ich rozmiary } & Polska (w \%) & UE (w \%) \\
\hline Kredyty & 53,1 & 63,3 \\
\hline Finansowanie dłużne pozabankowe & 18,4 & 14,0 \\
\hline Finansowanie udziałowe (VC i BA) & 6,0 & 6,8 \\
\hline Finansowanie dłużne typu equity & 6,2 & 3,1 \\
\hline Inne & 11,4 & 5,7 \\
\hline Trudno powiedzieć / brak odpowiedzi & 4,9 & 7,1 \\
\hline Razem & 100,0 & 100,0 \\
\hline
\end{tabular}

Źródło: opracowanie własne na podstawie SMEs Access to Finance (2011)

VC - venture capital rozumiany jest tu jako inwestycje (średnio- bądź długoterminowe) w przedsiębiorstwa niepubliczne znajdujące się we wczesnych fazach rozwoju, często obarczone wysokim ryzykiem niepowodzenia inwestycji i prowadzone przez wyspecjalizowane podmioty (fundusze venture capital). Zgodnie z nomenklaturą Europejskiego Stowarzyszenia Private Equity i Venture Capital (European Private Equity \& Venture Capital Association) inwestycje venture capital są podzbiorem inwestycji private equity i obejmują inwestycje znajdujące się na wczesnych etapach rozwoju, tj. na etapie zalążkowym, startu oraz wczesnej ekspansji (seed, startup i later stage venture). Zamienne stosowanie tych pojęć nie jest zatem poprawne (NBP, 2018). BA jest to business angels, czyli osoby fizyczne, inwestujące niewielkie kwoty w przedsięwzięcia o dużym potencjale wzrostu w przyszłości. To inwestorzy, którzy wnoszą do przedsięwzięcia oprócz środków finansowych także swoje doświadczenie, operacyjny know-how oraz zdolności (Anioły biznesu, 2018).

W celu uzyskania informacji na temat finansowania działalności przedsiębiorstw w Polsce przeprowadzono badanie ankietowe w formie elektronicznej. Ankieta zawierała 12 pytań zamkniętych. Została ona rozesłana do 600 przedsiębiorstw z sektora usług, mających swoją siedzibę na terenie Rzeczypospolitej Polskiej. Przedsiębiorstwa wybrane zostały drogą losową, tak aby otrzymane wyniki były reprezentatywne. Również w sposób losowy wytypowano osiem województw, spośród których dokonano selekcji podmiotów: lubelskie, łódzkie, małopolskie, mazowieckie, podkarpackie, podlaskie, śląskie, świętokrzyskie. Ankiety zostały wysłane w równej liczbie do przedsiębiorstw zlokalizowanych w poszczególnych województwach. Przy doborze podmiotów do badań przede wszystkim kierowano się rodzajem prowadzonej działalności przedsiębiorstw z sektora usług bądź faktem, że głównym obszarem działalności tychże firm było świadczenie usług. Informację zwrotną uzyskano od 73 podmiotów z ośmiu województw, co stanowiło ok. $12 \%$ całej próby.

Na podstawie otrzymanych wyników przeprowadzono analizę źródeł finansowania przedsiębiorstw. Najistotniejsze wyniki badań przedstawiono w niniejszej publikacji. Poniżej przytoczono najważniejsze odpowiedzi na pytania, które w sposób istotny wnoszą wkład w poruszaną problematykę. Pytania dotyczące zewnętrznych źródeł finansowania uwzględnione $\mathrm{w}$ artykule to:

- znajomość zewnętrznych źródeł finansowania;

- źródła kapitałów obcych obecnie wykorzystywane w działalności gospodarczej;

- determinanty wpływające na wybór rodzaju zewnętrznych źródeł finansowania;

- dostępność źródeł finansowania dla sektora usług (według badanych przedsiębiorstw); 
- planowanie wykorzystania w przyszłości zewnętrznych źródeł finansowania.

Kredyt bankowy (56\% wskazań) i kupiecki (35\% wskazań) okazały się najlepiej znane wśród respondentów spośród innych podanych zewnętrznych źródeł finansowania (tab. 3).

Tab. 3. Znajomość zewnętrznych źródeł finansowania

\begin{tabular}{|l|c|c|c|}
\hline \multicolumn{1}{|c|}{ Wyszczególnienie } & Brak znajomości & Średnia znajomość & $\begin{array}{c}\text { Bardzo dobra } \\
\text { znajomość }\end{array}$ \\
\hline Kredyt bankowy & 2 & 15 & 56 \\
\hline Kredyt kupiecki & 7 & 31 & 35 \\
\hline Factoring & 28 & 32 & 13 \\
\hline Leasing & 40 & 35 & 31 \\
\hline Dotacje oraz subwencje & 30 & 25 & 8 \\
\hline $\begin{array}{l}\text { Pożyczki od innych przedsiębiorstw } \\
\text { niebędących bankami ani SKOK-ami }\end{array}$ & 3 & 37 & 6 \\
\hline Pożyczki od rodziny & 46 & 10 & 60 \\
\hline Ulgi podatkowe & 39 & 20 & 7 \\
\hline Gwarancje rządowe & 25 & 9 \\
\hline
\end{tabular}

Źródło: opracowanie własne na podstawie przeprowadzonych badań

Wśród źródeł kapitałów obcych wykorzystywanych w działalności gospodarczej w opinii badanych podmiotów najczęściej wykorzystuje się kredyt bankowy (49\%) i kredyt kupiecki (30\%) (tab. 4).

Tab. 4. Źródła kapitałów obcych obecnie wykorzystywane w działalności gospodarczej

\begin{tabular}{|l|c|}
\hline \multicolumn{1}{|c|}{ Wyszczególnienie } & Liczba wskazań \\
\hline Kredyt bankowy & 49 \\
\hline Kredyt kupiecki & 30 \\
\hline Factoring & 8 \\
\hline Leasing & 29 \\
\hline Dotacje oraz subwencje & 15 \\
\hline Pożyczki od innych przedsiębiorstw niebędących bankami ani SKOK-ami & 9 \\
\hline Pożyczki od rodziny & 8 \\
\hline Ulgi podatkowe & 7 \\
\hline Gwarancje rządowe & 0 \\
\hline
\end{tabular}

Źródło: opracowanie własne na podstawie przeprowadzonych badań

Kolejne pytanie w kwestionariuszu ankietowym dotyczyło determinant wpływających na wybór rodzaju zewnętrznych źródeł finansowania. Najwięcej wskazań dotyczyło: wysokości opłat i prowizji (47\%), poziomu skomplikowania procedur i liczby wymaganych dokumentów (44\%) oraz prostych zabezpieczeń lub ich braku (38\%) (tab. 5).

Tab. 5. Determinanty wpływające na wybór rodzaju zewnętrznych źródeł finansowania

\begin{tabular}{|l|c|}
\hline \multicolumn{1}{|c|}{ Wyszczególnienie } & Liczba odpowiedzi \\
\hline Wysokość opłat i prowizji & 47 \\
\hline Poziom skomplikowania procedury i liczba wymaganych dokumentów & 44 \\
\hline Wymagane warunki do spełnienia & 37 \\
\hline
\end{tabular}




\begin{tabular}{|l|c|}
\hline Możliwość szybkiego otrzymania kapitału & 36 \\
\hline Proste zabezpieczenie/brak zabezpieczenia & 38 \\
\hline Opinie innych firm & 21 \\
\hline Inne & 3 \\
\hline
\end{tabular}

Źródło: opracowanie własne na podstawie przeprowadzonych badań

W opinii respondentów największą dostępnością spośród źródeł finansowania przedsiębiorstw w sektorze usług cechowały się kredyt bankowy (51\% odpowiedzi „bardzo dobry dostęp”) oraz kredyt kupiecki (36\% odpowiedzi „bardzo dobry dostęp”) (tab. 6).

Tab. 6. Dostępność źródeł finansowania dla sektora usług (według badanych przedsiębiorstw)

\begin{tabular}{|l|c|c|c|c|}
\hline \multicolumn{1}{|c|}{ Wyszczególnienie } & Brak dostępu & Średni dostęp & $\begin{array}{c}\text { Bardzo dobry } \\
\text { dostęp }\end{array}$ & $\begin{array}{c}\text { Brak opinii / nie } \\
\text { mam wiedzy }\end{array}$ \\
\hline Kredyt bankowy & 2 & 13 & 51 & 7 \\
\hline Kredyt kupiecki & 7 & 26 & 36 & 4 \\
\hline Factoring & 18 & 36 & 7 & 12 \\
\hline Leasing & 17 & 39 & 5 & 9 \\
\hline Dotacje oraz subwencje & 30 & 27 & 20 & 13 \\
\hline $\begin{array}{l}\text { Pożyczki od innych } \\
\text { przedsiębiorstw niebędących } \\
\text { bankami ani SKOK-ami }\end{array}$ & 10 & 30 & 15 & 17 \\
\hline Pożyczki od rodziny & 20 & 21 & 12 & 8 \\
\hline Ulgi podatkowe & 33 & 20 & 17 & 19 \\
\hline Gwarancje rządowe & 20 & 17 & & 7 \\
\hline
\end{tabular}

Źródło: opracowanie własne na podstawie przeprowadzonych badań

Ostatnie pytanie z zakresu źródeł finansowania w kwestionariuszu ankietowym dotyczyło przyszłości, tj. planowania skorzystania z zewnętrznych źródeł finansowania. Badani przedsiębiorcy w 45\% wskazali, iż w przyszłości skorzystają z kredytu bankowego, a w 20\% - z kredytu kupieckiego. Na trzecim miejscu uplasował się leasing z 20\% udzielonych odpowiedzi (tab. 7).

Tab. 7. Planowanie wykorzystania w przyszłości zewnętrznych źródeł finansowania

\begin{tabular}{|l|c|}
\hline \multicolumn{1}{|c|}{ Wyszczególnienie } & Liczba wskazań \\
\hline Kredyt bankowy & 45 \\
\hline Kredyt kupiecki & 20 \\
\hline Factoring & 18 \\
\hline Leasing & 17 \\
\hline Dotacje oraz subwencje & 9 \\
\hline Pożyczki od innych przedsiębiorstw niebędących bankami ani SKOK-ami & 3 \\
\hline Pożyczki od rodziny & 7 \\
\hline Ulgi podatkowe & 3 \\
\hline Gwarancje rządowe & 0 \\
\hline Inne & 2 \\
\hline Nie przewiduję / nie potrzebuję & \\
\hline
\end{tabular}

Źródło: opracowanie własne na podstawie przeprowadzonych badań 
Z przeprowadzonej analizy jednoznacznie wynika, iż kredyt bankowy jest najpopularniejszym zewnętrznym źródłem finansowania przedsiębiorstw również w sektorze usług. Wyniki badań dały obraz znajomości dostępnych źródeł i preferencji badanych podmiotów gospodarczych. Udzielone odpowiedzi są zbieżne z przytaczanymi w artykule badaniami przeprowadzonymi m.in. przez Związek Banków Polskich przy współpracy z Cetrum Badań Marketingowych.

\section{PodsumoWANIE}

Obecnie dość powszechne stało się wykorzystywanie w mediach przekazu na temat łatwo dostępnych środków finansowych. Na przestrzeni ostatnich kilkudziesięciu lat zwiększyły się możliwości sięgnięcia po różnego rodzaju środki finansowe na rozpoczęcie lub rozwinięcie działalności gospodarczej. Mamy do czynienia z coraz to nowymi źródłami finansowania oraz tzw. alternatywnymi źródłami finansowania. Przedsiębiorcy mogą korzystać z wielu rodzajów przeznaczonych dla nich środków finansowych, począwszy od dotacji, pożyczek zwrotnych i bezzwrotnych, po platformy crowdfundingowe, wsparcie aniołów biznesu czy inwestorów dysponujących venture capital.

Pomimo wzrostu liczby różnorodnych źródeł finansowych nadal najważniejszym ze źródeł - poza środkami własnymi - pozostają kredyty bankowe. Przytoczone statystyki i wyniki badań ankietowych pokazują, iż w sektorze przedsiębiorstw usługowych kredyty to główne źródło zewnętrznego finansowania. Kredyty są istotnym wsparciem w rozwoju działalności gospodarczej. Stanowią swego rodzaju pomoc w bieżącym funkcjonowaniu działalności, często zastępują również wymagany wkład własny przy ubieganiu się przedsiębiorcy o dotację z funduszy unijnych. Przeprowadzone badania potwierdzają postawioną hipotezę o popularności kredytu bankowego będącego nadal podstawowym zewnętrznym źródłem finansowania przedsiębiorstw usługowych.

Branża usługowa w Polsce to znaczący dział krajowej gospodarki, patrząc z perspektywy liczby zatrudnionej w niej ludności. Dzięki przedsiębiorstwom świadczącym usługi możliwe staje się zmniejszenie bezrobocia - w firmach zaliczanych do sektora usług pracuje obecnie co druga osoba aktywna zawodowo. Jest to także sektor, który w ostatnich latach charakteryzował się największą dynamiką rozwoju. Przyrost przedsiębiorstw oraz inwestycji z branży usług systematycznie wzrasta (Wróbel, 2014). Rośnie także rola i znaczenie sektora usług w polskiej gospodarce. Od początku przemian społeczno-gospodarczych z lat 1989-1990 wkład w tworzenie wartości dodanej brutto i PKB sektora usług wzrósł - z ok. 50\% udziału w tworzeniu PKB w 1990 roku do ok. 65\% współcześnie. W statystykach międzynarodowych sektor usług uznawany jest za wyznacznik rozwoju gospodarki danego kraju (Woźniak, 2009: 37-39). Mimo dystansu, jaki nadal dzieli Polskę od państw najwyżej rozwiniętych, w ostatnich latach można mówić o poprawie sytuacji w tym zakresie.

Sektor usług to zarówno mikroprzedsiębiorstwa, jak i duże polskie przedsiębiorstwa działające w oparciu o nowoczesne modele biznesowe, które z sukcesem umiędzynaradawiają swoją działalność. Istotny z punktu widzenia rozwoju społeczno-gospodarczego kraju jest dalszy wzrost tego sektora, który możliwy będzie dzięki odpowiedniemu i rozsądnemu finansowaniu podmiotów gospodarczych (Ministerstwo Gospodarki, 2015: 203). 


\section{Literatura \\ References}

Anioły biznesu (2018, 14 maja). Pozyskano z http://www.private-equity.com.pl/anioly-biznesu-business-angels/

Brzozowski, T.T. (2013). Wiedza jako podstawowy czynnik rozwoju przemysłu i usług. Prace Komisji Geografii Przemysłu Polskiego Towarzystwa Geograficznego, 21, 390-404.

Chęciński, S. (2015). Źródła finansowania inwestycji w polskich przedsiębiorstwach. Zeszyty Naukowe Uniwersytetu Szczecińskiego. Finanse, rynki finansowe, ubezpieczenia, 855(74), 397-408.

Cyrek, M. (2011). Sektor usług w Polsce jako obszar zatrudnienia w uwarunkowaniach gospodarki opartej na wiedzy. Nierówności Społeczne a Wzrost Gospodarczy, 18, 451-467.

Kitowski, J. (2014). Kryterium oceny czynników subiektywnych w bankowych metodach weryfikacji zdolności kredytowej przedsiębiorstwa. Zeszyty Naukowe Uniwersytetu Szczecińskiego. Finanse, rynki finansowe, ubezpieczenia, 803(66), 345-360.

Korzeb, Z. (2016). Kredyty bankowe dla przedsiębiorców. W: J. Koleśnik (red.). Bankowość detaliczna. Warszawa: Difin.

Mały rocznik statystyczny Polski (2017, 29 listopada). Główny Urząd Statystyczny. Pozyskano z http://stat.gov.pl/obszary-tematyczne/roczniki-statystyczne/roczniki-statystyczne/ maly-rocznik-statystyczny-polski-2017,1,18.html

Ministerstwo Gospodarki (2015). Polska 2015 - Raport o stanie gospodarki. Warszawa.

Narodowy Bank Polski (NBP) (2015). Kredyt bankowy jako źródło finansowania działalności. Projekt „Przedsiębiorczość w praktyce”. Rzeszów.

Narodowy Bank Polski (NBP) (2018, 14 maja). Venture capial. Pozyskano z https://www.nbportal.pl/slownik/pozycje-slownika/venture-capital

Próchicka-Grabias, I., Szelągowska, A. (2006). Finansowanie działalności gospodarczej w Polsce. Wybrane aspekty. Warszawa: CeDeWu.

Skórska, A. (2016). Determinanty i perspektywy rozwoju sektora usług w Polsce - zmiany wewnątrzsektorowe. Prace Komisji Geografii Przemysłu Polskiego Towarzystwa Geograficznego, 30, 7-20.

SMEs Access to Finance (2011). Komisja Europejska i Europejski Bank Centralny.

Ustawa z dnia 29 sierpnia 1997 roku - Prawo bankowe (Dz.U. z 1997 r. nr 140, poz. 939, z późn. $\mathrm{zm}$.).

Woźniak, M.G. (2009). Zmiany strukturalne gospodarki Polski po 1990 roku. Prace Komisji Geografii Przemysłu Polskiego Towarzystwa Geograficznego, 12, 33-43.

Wróbel, A. (2014). Rola sektora usług w rozwoju społeczno-gospodarczym i kształtowaniu gospodarki opartej na wiedzy w Polsce. Nierówności Społeczne a Wzrost Gospodarczy, 37, 306-319.

Zioło, Z. (2013). Rola przemysłu i usług w kształtowaniu gospodarki opartej na wiedzy. Prace Komisji Geografii Przemysłu Polskiego Towarzystwa Geograficznego, 21, 11-30.

Związek Banków Polskich (ZBP) (2017a, 29 listopada). Kredyt bankowy nadal najczęstsza forma finansowania zewnętrznego wśród przedsiębiorców. Pozyskano z https://zbp.pl/wydarzenia/archiwum/wydarzenia/2017/lipiec/kredyt-bankowy-nadal-najczestsza-forma-finansowania-zewnetrznego-wsrod-przedsiebiorstw

Związek Banków Polskich (ZBP) (2017b, 29 listopada). Polscy przedsiębiorcy o usługach bankowych. Pozyskano z https://zbp.pl/public/repozytorium/wydarzenia/images/maj_2016/ MSP/INDICATOR_i_ZBP-_Polscy_przedsibiorcy_o_uslugach_bankowych-prezentacja_1.pdf

Karolina Kozioł, mgr ekonomii, asystent, Uniwersytet Rzeszowski, Wydział Ekonomii, Katedra Ekonomiki i Zarządzania. Absolwentka Wydziału Ekonomii, od kilku lat związana ze środowiskiem start-upowym na Wydziale Ekonomii Uniwersytetu Rzeszowskiego. Główne zainteresowania naukowe koncentrują się wokół rozwoju przedsiębiorczości, w tym przedsiębiorczości start-upowej, czynników warunkujących powstawanie i wzrost start-upów, a także aspektów dotyczących ich finansowania.

Karolina Kozioł, M.Sc., graduated from the Department of Economics of the University of Rzeszow. A graduate of the Faculty of Economics, for several years associated with the startup environment at the Faculty of 
Economics of the University of Rzeszów. The main research interests are focused on the development of entrepreneurship, including startup entrepreneurship, factors determining the creation and growth of startups, as well as aspects of their financing.

\title{
Adres/address:
}

\author{
Uniwersytet Rzeszowski \\ Wydział Ekonomii \\ Katedra Finansów \\ ul. M. Ćwiklińskiej 2, 35-601 \\ e-mail: kakoziol@ur.edu.pl
}

Rafał Pitera, mgr ekonomii, asystent, Uniwersytet Rzeszowski, Wydział Ekonomii, Katedra Finansów. Absolwent Wydziału Ekonomii, od kilku lat związany z dziedziną finansów i bankowości. Główne obszary zainteresowań: sprawozdawczość i analiza finansowa, badanie i ocena kondycji finansowej przedsiębiorstw, optymalizacja podatkowa, analiza ulg podatkowych i ich wpływ na rozwój przedsiębiorczości.

Rafał Pitera, MA, graduated from the Department of Economics of the University of Rzeszow. A graduate of the Faculty of Economics, for several years has been involved in finance and banking. Main areas of interest: financial reporting and analysis, research and assessment of the financial condition of enterprises, tax optimization, tax relief analysis and their impact on entrepreneurship development.

\section{Adres/address:}

Uniwersytet Rzeszowski

Wydział Ekonomii

Katedra Finansów

ul. M. Ćwiklińskiej 2, 35-601 Rzeszów, Polska

e-mail: rpitera@ur.edu.pl 